\title{
長期在宅介護を行ったALS 罹病者遺族の生活環境の再編過程に関する研究 STUDY OF THE RESTORATION PROCESS OF THE LIVING ENVIRONMENTS OF BEREAVED FAMILIES THAT HAD UNDERTAKEN LONG-TERM AT-HOME CARE FOR ALS PATIENTS
}

\author{
亀屋 惠三子*, 足立 啓** \\ Emiko KAMEYA and Kei ADACHI
}

\begin{abstract}
By focusing on the changes that can be made to houses to establish a point from which bereaved families can return to their communities, with the aim of clarifying the course of house restoration from a nursing to a living environment, we conducted a questionnaire survey of affected families, and a case-based survey to understand the space available in their homes after undertaking the long-term at-home care for an ALS patient.

1) After the death of an ALS patient, the way in which a house is restored can be roughly classified into four types, namely, restoration, partial restoration, reconstruction, and no change. Most bereaved families undertook reconstruction. This trend was more frequently seen in urban LDK-type houses. 2) Family members, who had lost their spouses after long-term at-home care, showed a marked tendency to use a living room or habitable room adjacent to the living room as the room for Buddhist rituals or to display photos of their deceased spouse. Consequently, we can conclude that the home environment is such that the location relationship remains unchanged even after the death. After the death of an ALS patient is formed by subconsciousness to a residence, the length of the recuperation period and relationship with how to live and people who passed away.
\end{abstract}

Keywords : ALS patients, bereaved family, living environment restoration, house adaptation

ALS 罹病者，遺族，生活環境の再編，住まい方

\section{1. はじめに}

\section{1 研究の背景と目的}

2000 年の介護保険サービスの開始に伴い、在宅支援が拡充してき ている。在宅療養を行うためには、住まいの中に当初予期しなかっ た「療養」機能を付す必要があり、療養室を中心として医療機器が ベッド周りに集積し、動線確保なども相俟って療養室が「生活」「療 養」「ケアを受ける (罹病者)」「ケアを与える (家族・ケア従事者)」 「食事」「接客」など多くの場として使用されるようになる。即ち、 療養室を中心に住まいが一時的に膨張するという変化であり、高齢 者の住まい方研究を中心に指摘されている注1)。

しかし、実際の生活はこれを越えて、療養が終わったのちに生活 環境が変化し、住まいが収縮していくことが予測される。これらの 変遷を「療養前」「療養中」「現在 (療養後)」の 3 段階で捉えること でその様態を掴むことができるのではないかと考えた。そこで本研 究では療養期間が長く介護量が多いとされる筋委縮性側索硬化症

（以下、ALS とする）罹病者の遺族を対象に注 2)、今後の住計画の一 助となる療養環境から生活環境へと再編していく過程や再編に必要 な環境要素を明らかにすることを目的とする。

\section{2 既往研究と本研究の位置付け}

ALS 罹病者における在宅療養環境に関する研究は、亀屋らにおけ る生活時間や住まい方に関する研究 ${ }^{5)}$ と長島らにおける住環境の整
備に関する研究 ${ }^{6)}$ に限定される。その中で亀屋は、(1)家族介護者に よる 10 時間にも及ぶ介護量の多さ、(2)意思伝達の可否が住まい方に 大きな影響を及ぼすことなどを指摘した。一方で長島は、日常生活 動作や福祉機器の点から病気の進行を見据えた住環境整備の必要性 を明らかにした。どちらも療養中の罹病者・家族を対象としたもの であり、遺族の視点での生活環境の再編という視点は含んでいない。 一方、遺族ケアに関する研究は、看護・心理学系でみられており、 代表的なものに坂口による悲嘆（グリーフ）ケアの研究がある。そ の一連の研究の中で坂口は、「死別後の危機状態だからといって、急 に家族が寄り添ったり、コミュニケーションがオープンになるわけ ではない」ことを明らかにした上で、「長期的な展望において、家族 機能寸なわち『家族の潜在力』の改善は大切である」と述べている 7)。住宅における看取りに関しては、医療看護をはじめ、介護者や 看護師による評価に関する研究 ${ }^{8)}$ 、9) や、在宅死を可能にする課題 の検討などがみられている ${ }^{10)}$ 。しかしながら、住まいに関連した研 究に限定すると、遺族や看取りに関する学術論文はなく山本ら ${ }^{11}$ 、 大槻ら ${ }^{12)}$ によるがん患者を対象とした看取りに関する研究など数 編のみになる。療養環境に関しては山本らの要介護高齢者の続き間 による住まい方による研究 ${ }^{2)}$ 、井上らによる在宅サービスを活用す る高齢者の住まいに関する研究 ${ }^{3)}$ において療養時の住まい方が明ら かにされている。そこで、本研究ではこれら既往研究による成果を

本論文は，文献 14,15)で報告した内容に追加分析・修正を加え発展させたものである

* 神戸市立工業高等専門学校都市工学科 准教授・博士(工学) Assoc. Prof., Dept. of Civil Engineering, Kobe City College of Technology, Dr.Eng.

**＼cjkstart和歌山大学システム工学部 教授・工博 Prof., Dept of System Engineering, Wakayama Univ, Dr.Eng. 
踏まえつつ、分析を行っていくこととする。

\section{3 分析の枠組み}

まず遺族の住まいや住まい方の全体像を明らかにするため、療養 室の位置や場、住まいの様式の特徵を整理する。次いで生活環境を 「療養前」「療養中」「現在 (療養後)」の 3 つの時期に分けて事例を 提示し、再編過程の特徵について分類・考察を行う。

続いて、再編に必要な環境要素を抽出するために「現在 (療養後)」 の住まい方より特に仏間・遺影の位置に着目し分析を行う。これに より仏間や遺影の位置から現在の故人との関係性についても探るこ とができると考えたためである。また、在宅療養を行った遺族は基 本的には自らの意思で住み続けるか転居を行うかを決定し、その後 の生活環境を構築していくが、自分の意思を尊重できない 2 事例が 存在した。(1)天災により住まいを失った事例と、(2)逝去後に主介護 者以外の遺族の強い意向により環境移行を余儀なくされた事例であ

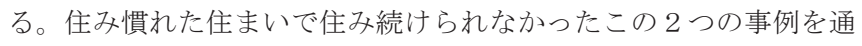
して、再編に必要な環境要素を補足的に捉える。

\section{2. 調査の概要}

\section{1 調査対象者と方法・時期}

ALS 協会(1)山形県支部・ (2)宮城県支部・ (3)愛知県支部・ (4)近畿ブ ロックに協力を依頼し、調查協力者を得た注3)。また、協会以外で
は、(5)インターネットで検索などを行いコンタクトの取れた ALS の 遺族および罹病者が存命中に ALS 協会岩手県支部より紹介を受けた 後、遺族となった 1 名を加えている注4)。(1)山形県と (2)宮城県に関 しては、関係者よりアンケートを送付してもらい、書面に訪問調査 の可否を選択してもらう方法を取った。(3)愛知県支部は事務局を運 営する遺族委員に 10 名程度協力してくれそうな遺族を選出しても らい、遺族委員が電話にて訪問調查を交涉する方法を取った。それ と同時に会報誌にも調查協力の依頼を掲載した。(4)近畿ブロック会 報誌に調查協力依頼を掲載したが、連絡が得られなかった。その後、 会報誌の相談欄を基に遺族に連絡を取り、個別に交涉した。以下、 対象者の詳細である。転居により療養時の住まいの空間調査が不可 能だった対象者に対しては、ヒアリングを行いながら図面を復元す る方法を取った。なお、調查時期は 2012.8～2013.8 までである注5)。 (1)山形県支部：アンケート回答者 14 名（回答率 $41.2 \%$ )。ただし、 1 名は入院生活が主だったため、対象者より除外した。回答者の 内、訪問調查の協力者は 2 名。

(2)宮城県支部：アンケート回答者 5 名（回答率 $55.6 \%$ )。そのうち 訪問調查協力者は 4 名。

(3)愛知県支部 : アンケート回答者 6 名（電話で依頼）。訪問調查協力 者は 5 名（内 2 名は図面を復元）。

(4)近畿ブロック:アンケート回答者 1 名。訪問調查協力者は 1 名（図

表 1 調査対象者の主体条件

\begin{tabular}{|c|c|c|c|c|c|c|c|c|c|c|c|c|c|c|}
\hline 対象者 & M1 & $\underline{\mathrm{M} 2}$ & M3 & $\mathrm{F} 4$ & F5 & F6 & F7 & M8 & F9 & $\mathrm{F} 10$ & $\mathrm{~F} 11$ & M12 & F13 & F14 \\
\hline 都道府県 & 山形県 & 山形県 & 山形県 & 山形県 & 山形県 & 山形県 & 山形県 & 山形県 & 山形県 & 山形県 & 山形県 & 山形県 & 山形県 & 大阪府 \\
\hline 主介護者 & 夫 & 夫 & 息子 & 娘 & 妻 & 妻 & 妻 & 夫 & 妻 & 妻 & 娘 & 妻 & 妻 & 妻 \\
\hline 回答者 & 夫 & 夫 & 息子 & 娘 & 妻 & 妻 & 妻 & 夫 & 妻 & 妻 & 娘 & 妻 & 妻 & 妻 \\
\hline $\begin{array}{l}\text { 同居家族 } \\
\text { (現在) }\end{array}$ & なし & なし & 母、姉2人 & なし & なし & $\begin{array}{c}\text { 息子夫 } \\
\text { 婦、孫2人 }\end{array}$ & なし & なし & なし & なし & \begin{tabular}{|l} 
夫、娘2、 \\
息子1
\end{tabular} & なし & なし & \begin{tabular}{|l|} 
義母、娘 \\
2、息子1 \\
人
\end{tabular} \\
\hline 亡くなった日 & 2012.2 & 2010.6 & 1995.4 & 2008.7 & 2004.7 & 2006.11 & 2008.7 & 2002.7 & 2008.11 & 2005.12 & - & 2010.1 & 2009.7 & 2004.9 \\
\hline 亡くなった年齢 & 64 & 64 & 70 & 79 & 60 & 54 & 71 & 41 & 65 & 76 & 85 & 65 & 70 & 49 \\
\hline $\begin{array}{c}\begin{array}{c}\text { 主介護者の年齢 } \\
\text { (当時) }\end{array} \\
\end{array}$ & 68 & 69 & 38 & 46 & 57 & 53 & 66 & 51 & 58 & 71 & - & 59 & 67 & 41 \\
\hline $\begin{array}{c}\text { 主介護者の年齢 } \\
\text { (現在) }\end{array}$ & 68 & 70 & 50 & 50 & 63 & 58 & 70 & 61 & 61 & 77 & 61 & 61 & 70 & 51 \\
\hline $\begin{array}{c}\begin{array}{l}\text { 在宅療養期間 } \\
(ヶ \text { 月 })\end{array} \\
\end{array}$ & 2 & 108 & 12 & 7 & 60 & 48 & 64 & 24 & 84 & 36 & 60 & 90 & 48 & 48 \\
\hline 逝去後の経過年数 & 7ヶ月 & $\begin{array}{c}\text { 1年 } \\
\text { 1ヶ月 }\end{array}$ & $\begin{array}{l}\text { 17年 } \\
\text { 3ヶ月 }\end{array}$ & 4年 & 8年 & $\begin{array}{c}5 \text { 年 } \\
6 \text { 月月 }\end{array}$ & 4年 & 10 年 & $\begin{array}{c}\text { 3年 } \\
\text { 7ヶ月 }\end{array}$ & $\begin{array}{c}6 \text { 年 } \\
\text { 7ヶ月 }\end{array}$ & - & $\begin{array}{c}2 \text { 年 } \\
6 \text { 只 }\end{array}$ & $\begin{array}{c}3 \text { 年 } \\
2 ヶ \text { 月 }\end{array}$ & $\begin{array}{l}10 \text { 年 } \\
\text { 9ヶ月 }\end{array}$ \\
\hline $\begin{array}{l}\text { 人工呼吸器の装着 } \\
\text { の有無と意思疎通 }\end{array}$ & 有/可 & 有/可 & 有/不明 & 有/不明 & 有/不明 & 有/不明 & 有/不明 & 無/不明 & 有/不明 & 無/不明 & 有/不明 & 有/不明 & 無/不明 & 有/不明 \\
\hline 住宅形態 (療養中) & 一戸建て & 一戸建て & 一戸建て & 一戸建て & 一戸建て & 一戸建て & 一戸建て & 一戸建て & 一戸建て & 一戸建て & 一戸建て & 一戸建て & 一戸建て & 一戸建て \\
\hline 築年数 & 45年 & 40年 & 26年 & 31年 & 30年 & 24-35年 & 35年 & 18年 & 30年 & 未回答 & 48年 & 20年 & 26年 & 25年 \\
\hline $\begin{array}{l}\text { 住宅改修の有無 } \\
\text { ()内は療養中の変化 }\end{array}$ & 有 & 有 & 無 & 無 & 有 & 有 & 有 & 無 & 有 & 有 & 無 & 有 & 有 & 無 \\
\hline 対象者 & F15 & F16 & F17 & F18 & F19 & $\underline{F 20}$ & F21 & $\underline{\mathrm{M} 22}$ & F23 & F24 & M25(1) & M25(2) & F26 & $\underline{F 27}$ \\
\hline 都道府県 & 大阪府 & 愛知県 & 愛知県 & 愛知県 & 愛知県 & 愛知県 & 愛知県 & 宮城県 & 宮城県 & 宮城県 & 宮城県 & 宮城県 & 宮城県 & 岩手県 \\
\hline 主介護者 & 妻 & 義娘 (嫁) & 妻 & 妻 & 妻 & 妻 & 妻 & 夫 & 妻 & 妻 & 父 & 夫 & 妻 & 娘 \\
\hline 回答者 & 妻 & 義娘 (嫁) & 妻 & 妻 & 娘 & 妻 & 妻 & 夫 & 妻 & 妻 & 父 & 夫 & 妻 & 娘 \\
\hline $\begin{array}{c}\text { 同居家族 } \\
\text { (現在) }\end{array}$ & なし & $\begin{array}{l}\text { 義父、夫 } \\
\text { (単身赴 } \\
\text { 任)、息子 }\end{array}$ & $\begin{array}{l}\text { 長女、 } \\
\text { 長男 }\end{array}$ & なし & \begin{tabular}{|l} 
なし(主介 \\
護者)施設
\end{tabular} & $\begin{array}{c}\text { 二女夫 } \\
\text { 婦·孫2人 }\end{array}$ & $\begin{array}{l}\text { 息子夫 } \\
\text { 婦、孫 }\end{array}$ & なし & なし & なし & なし & なし & なし & なし \\
\hline 亡くなった日 & 2011.4 & 2007.8 & 2010.12 & 2012.2 & 2010.4 & 2009.9 & 2012.6 & 2012.5 & 2000.2 & 2013.11 & 2009.4 & 2012.6 & 2007.1 & 2008.1 \\
\hline 亡くなった年齢 & 74 & 77 & 74 & 68 & 76 & 59 & 74 & 61 & 61 & 62 & 43 & 76 & 57 & 68 \\
\hline $\begin{array}{c}\text { 主介護者の年齢 } \\
\text { (当時) }\end{array}$ & 67 & 45 & 64 & 66 & 53 & 56 & 71 & 61 & 61 & 58 & 73 & 76 & 59 & 41 \\
\hline $\begin{array}{c}\text { 主介護者の年齢 } \\
\text { (現在) }\end{array}$ & 69 & 50 & 65 & 67 & 54 & 58 & 71 & 62 & 74 & 60 & 78 & 78 & 65 & 46 \\
\hline $\begin{array}{c}\text { 在宅療養期間 } \\
(\text { 足 })\end{array}$ & 60 & 120 & 44 & 110 & 12 & 72 & 102 & 38 & 144 & 276 & 78 & 181 & 84 & 84 \\
\hline 逝去後の経過年数 & $\begin{array}{c}\text { 2年 } \\
\text { 2ケ月 }\end{array}$ & 5 年 & $\begin{array}{c}1 \text { 年 } \\
\text { 8ケ月 }\end{array}$ & 9ヶ月 & $\begin{array}{c}\text { 1年 } \\
\text { 11ヶ月 }\end{array}$ & $\begin{array}{c}2 \text { 年 } \\
6 \text { 年月 }\end{array}$ & $\begin{array}{c}1 \text { 年 } \\
6 \text { 年月 }\end{array}$ & $\begin{array}{c}\text { 1年 } \\
\text { 3ヶ月 }\end{array}$ & $\begin{array}{l}13 \text { 年 } \\
6 \text { 个月 }\end{array}$ & $\begin{array}{c}2 \text { 年 } \\
8 \text { 月 }\end{array}$ & $\begin{array}{c}\text { 2年 } \\
\text { 2ヶ月 }\end{array}$ & $\begin{array}{c}6 \text { 年 } \\
\text { 4ヶ月 }\end{array}$ & $\begin{array}{c}6 \text { 年 } \\
\text { 7ヶ月 }\end{array}$ & $\begin{array}{c}\text { 5年 } \\
\text { 7ヶ月 }\end{array}$ \\
\hline $\begin{array}{l}\text { 人工呼吸器の装着 } \\
\text { の有無と意思疎通 }\end{array}$ & 無/可 & 無/可 & 無/可 & 無/可 & 無/不明 & 無/可 & 無/可 & 無/可 & 有/可 & 有/可 & 有/可 & 有/可 & 有/不明 & 有/可 \\
\hline 住宅形態 (療養中) & 一戸建て & 一戸建て & 一戸建て & 一戸建て & 一戸建て & 一戸建て & 一戸建て & 一戸建て & 一戸建て & 一戸建て & 一戸建て & 一戸建て & マンション & 一戸建て \\
\hline 築年数 & 34年 & 14年 & 4年 & 39年 & 40年 & 22年 & 11年 & 24年 & 20 年 & 31年 & 38年 & 38年 & 10年 & 35年 \\
\hline $\begin{array}{l}\text { 住宅改修の有無 } \\
\text { ()内は療養中の変化 }\end{array}$ & 有 & 有 (新築) & 無 (新築) & 有 & 有 & 有 & 無 & 有 & 無 (新築) & 有 & 有 & 有 & 無 (転居) & 有 \\
\hline
\end{tabular}

注：対象者名に下線のある者は訪問調査対象者を示す。なお、M25 は一人で 2 名の ALS 罹病者（娘 (1)、妻 (2)）を看ていた 
面を復元)

(5)インターネットでの検索・親交のある遺族 : アンケート回答者 2

名。訪問調査協力者は 1 名（図面を復元）

計 アンケート対象者 27 名 訪問調査対象者（復元含む）：13名

\section{2 調査内容}

調査はアンケート調查（訪問時のヒアリングアンケート含む）と 訪問調查を行った。主な内容を以下に記す。

アンケート項目：・主体条件（遺族、罹病者の特性）

・生活環境（居室使用変化や整理状況など）

・臨死期の対応と仏事の様子・交流関係 など

訪問調查項目：・空間描画及び生活環境、住まい方の変遷の把握

\section{3. 調査対象者の主体条件（表 1)}

表 1 は訪問調査を含む全調查協力者 27 名の主体条件を示している。 調查対象者は、60 代以上の高齢層が 7 割にも上り、罹病者逝去後に 一人暮らしとなった人が半数以上いる。在宅療養期間は、バラつき があるものの平均 6.5 年と長く、事例調查を行った全ての対象者は 人工呼吸器の装着の有無に関わらず最期まで意思疎通が可能であっ た。山本らの在宅がん遺族の調査 ${ }^{11)}$ では、アンケートに回答した 遺族 186 名のうち 6 割が高齢者以外で同居家族数は平均 4.4 名とい う結果となっており、療養期間も 1 年末満と短い。ALS はがんより もやや高齢者の割合が高く、同居家族が少ない対象者層であること がわかる。

\section{4. 生活環境の変遷}

\section{1 療養室の位置（図 1、表 2、表 3)}

回答のあった 22 名の療養室の場所を整理した（図 1)。これをみ ると「和室 (居間との位置関係は不明)」が最も多く、約半数であっ た。次いで居間、寝室となっていた。療養室の位置に関してはヒア リングなどで把握できた 13 名の療養室の位置を整理した（表 2）。 これをみると、居間もしくは居間との続き間での療養が最も多く 7 割を占める。在宅がん患者の研究結果注 6) と比較してみると、部屋 の場所は定かではないが 186 名を対象とした同アンケート調査でも 7 割が続き間で療養していたとの結果が出ている。

罹病者と主介護者の寝室の位置関係（表 3）をみると、同室や隣 室が全体の 8 割を占めており、主介護者室と近接することが確認さ れた。このような傾向は、前掲の在宅がん患者の研究においても $85 \%$ (125人/146人) みられ、介護を要する高齢者の住まいに関する研 究結果においても、ADL のレベルが低下寸ると「食」「寝」の場が一 体となることが明らかとなっている2、3)。介護を伴う対象者に共通 してみられる特徴であると捉えることができる。

\section{2 住まいの様式と変遷（図 2)}

図 2 は訪問調查承諾者 13 名中 10 名の療養前から現在までの住ま い方の変遷を示している。他、3 名については F15, F20 は復元した 療養中の住まいしかなく、M22 は震災の影響により療養途中の住ま いが消失したため、療養中の環境を充分に再現できなかった。また、 M25 については一人で 2 名を介護するという他事例とは異なる特徵 を持っており、並列に記載することが難しかったため、図 2 に住ま い方のみ記載する方法を取った。

住まいは全て戸建てであり、住まいの様式は、続き間を中心とし

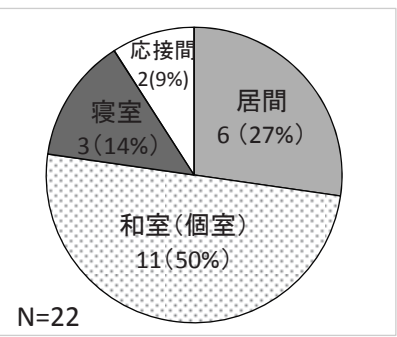

図 1 療養後期の療養室

表 2 療養室の位置 表 3 療養室と主介護者の寝室の位置

\begin{tabular}{|c|c|c|c|}
\hline & 事例数-事例名 & & 事例数 (\%) \\
\hline 居間 & 5 (F17,F20,M22,F23,F24) & 同室 & $10(40 \%)$ \\
\hline 居間との続き間 & 4 (M2,F18,F21,F27) & 隣り & 11 (44\%) \\
\hline 続き間 & $2(\mathrm{M} 1, \mathrm{~F} 15)$ & 部屋を挟んで隣り & 0 \\
\hline 独立室 & 2 (F16,M25) & 廊下を挟んで隣り & 0 \\
\hline 計 & 13 & 離れている & $4(16 \%)$ \\
\hline 療養室の広さ平均 & 9.3盢 & 計 & 25 \\
\hline
\end{tabular}

た地方続き間（連続間）型注7)、また LDK を基本とし個室で構成さ れる都市 LDK 型主8) の 2 つのタイプが中心であることがわかる。傾 向としては、地方連続間型（M1, M2, F18, F21）が 4 名、都市 LDK 型 （F16, F17, F23, F24, M25, F27）が 6 名となっており、都市 LDK 型の住 宅が多くなっている。

続いて、住まい方の変遷に着目し考察していく。図 2 は、現在（調 查時）の住まい方を示し、それが療養前の住まい方とほぼ一緒にな っており、元の状態に戻ったものを「復元」、療養中と同じ家具が療 養室に置かれており、住まい方にやや変更がみられたものを「半構 築」、家具やしつらえを新たに变更したものを「再構築」、療養を通 して変化のないものを「変化なし」と整理した。住まいの様式と住 まいの変遷を分析してみると、復元・半構築は地方連続間型の傾向 がある住まいが 4 事例中 3 件該当している。他方、居間中心の都市 LDK 型は再構築の 4 事例全てが該当しており、その内 3 事例におい ては居間に療養室を設置する傾向がみられていた。

次に住まいの変遷の 4 つの類型の傾向を見ていくこととする。変 化がなかったものは 1 例であった。F 21 は療養初期に罹病者が骨折 して以来、施設入所となったため、特に生活の変化がみられなかっ た。臥床生活を住宅内で行わない場合は、住まい方に殆ど変化がな いことが窥える。

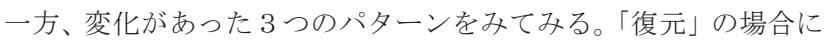
は、現在、元の療養室が空室となっていること、一人暮らしになっ ていることが特徴である。家族数が少ないため、居間と寝室の二室 での暮らしが主となることから、生活空間が縮小寸ることが確認さ れた。他方、復元でも再構築でもない「半構築」の M2 の事例がある。 たいていの遺族はレンタル品を返却寸る注9) のだが、M2 は罹病者が 使用していたベッドに愛着を見出し、それを買い取った経緯がある。 罹病者の逝去後、 1 年間は療養室を殆ど整理せず、意図的に保存し、 レンタルベッドの脇で療養中と同じように添い寝する生活を続けた。 1 周忌のあとに、意を決して模様替えを行い、図のように罹病者が 使用していたベッドに自身が就寝するという生活を作り上げた。壁 面などには、罹病者が見ていた同じ絵や写真が現在も飾られており、 同じ景色を楽しんでいるのだという。1 周忌までは、居間でくつろ ぎ、元療養室で就寝するという生活を送っていたが、模様替え以後、 居間で過ごすことも殆どなく、基本的には寝室中心の生活となった。 M2 も「こんな生活じゃいけないとは思うけど気力が湧かないんだよ 


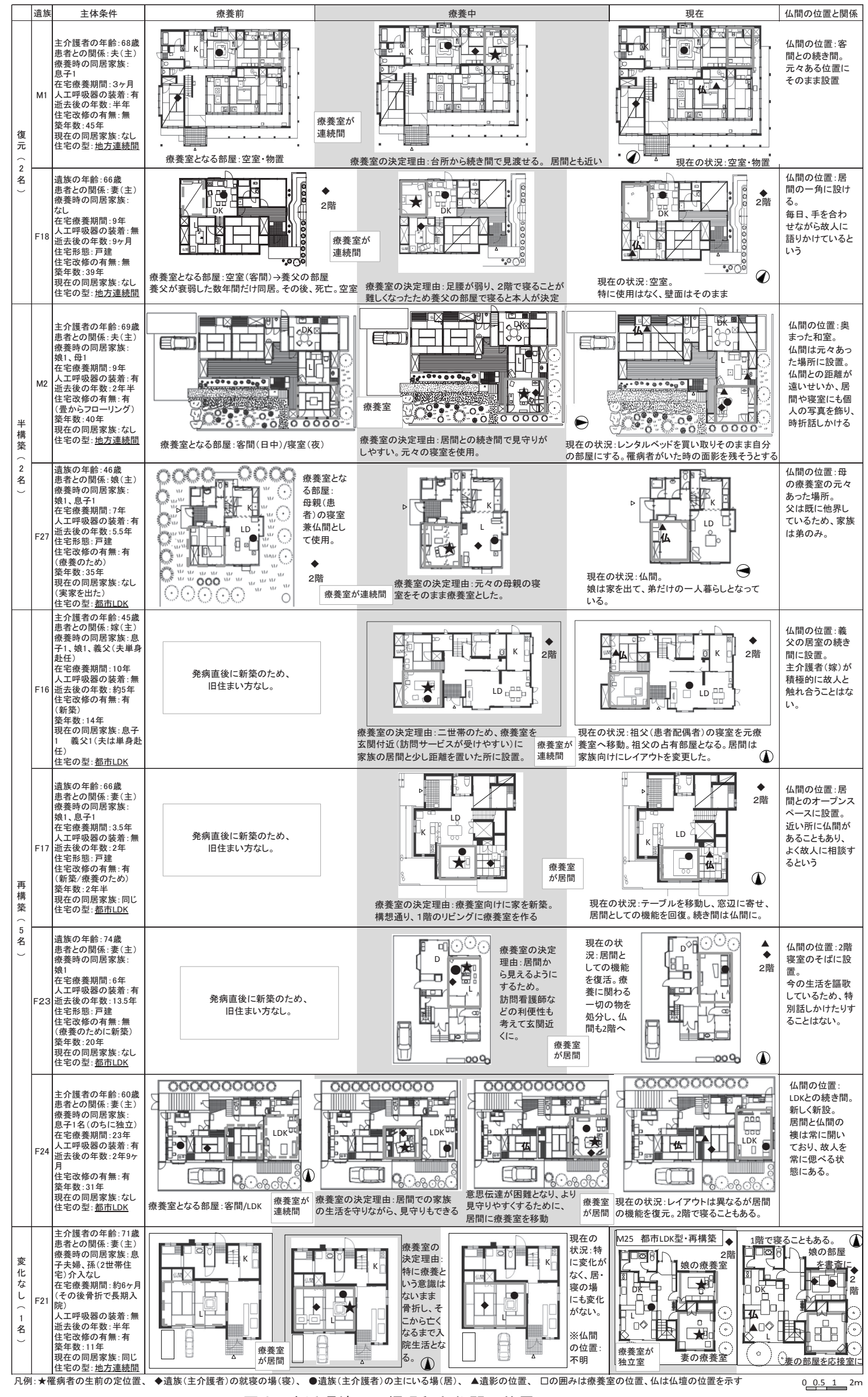

図 2 生活環境の再編過程と仏間の位置 
な」と語っており、無気力な状態が続いている。療養時と殁ど変わ らないしつらえとなっていることから、介護生活から抜け出せない 状態が、環境や住まい方にも現れている事例である。同じ半構築の F27 は、母親の療養室（寝室）を兼初ていた仏間を整理し、元の仏 間の機能を尊重した。居間のしつらえは F27 の添い寝が不要となっ たため、居間本来の機能を取り戻した。また弟と同居していては依 存的になると危機感を抱き、実家を離れて新しい仕事を持ち生活を 再出発させた。遺族のライフスタイルが変化した事例である。

他方、再構築が行われる事例が最も多い(F16, F17, F23, F24, M25)。 F16, F17, F23 の事例は療養に備えて家を新築するなど、住環境への 意識が高い集団である。またいずれも療養当時、同居家族がいるこ とも共通点である。F24 は、現在は一人暮らしであるが近くに住む 娘が度々孫を連れて遊びに来るため、孫が来ても対応できるように 居間を整えたという。近居家族との関係が再構築に影響を与えてい ると考えられる。また、F17, F24 は居間に療養室を構えていたこと もあり、ベッドや医療器具・痰の吸引を行うための用具一式を置い たままではわ問客などへの対応がしにくく、また罹病者とは無関係 な接客を居間で行うためには、居間としての機能を「再構築」せざ るを得なかったという事情があり、レンタル品の返却時（没後 1 ケ 月以内）と同じ時期に整理を行ったとのことであった注 ${ }^{10)}$ 。一方の F16 は、嫁という立場で主介護者を担当した。介護を終えたのち、 元療盖室を義父の部屋にし、居間も家族向けに模様替え行った。療 養中は車い寸を回転させるためモノを置けなかったり、常に訪問少 一ビス者の目に晒されたりしており、子供も居間に寄りつかない、 自分の家ではなかったみたいと振り返る。その反動が「家族の居間 をつくる」ということに向かわせたようだ。

一方の F 23 は、罹病者が逝去した瞬間、「解放された〜」と強く感 じ、療養にまつわる全ての物を積極的に廃棄し、新しい環境を構築 したという。「ただ一つ心残りなのは、今でも天井に介護用のレール が残っていることなの。これ、外してみたけど壁紙もそこだけない から駄目ね」と語り、介護の色を意図的に一掃させたいという強い 意志が感じられる事例である。再構築に対して強い意志のある F 23 とは反対に、外的な要因で再構築を行った M 25 の例がある。M 25 は 娘が亡くなった時は大きな失意に見舞われたと言い、その失意の中 で妻を介護していくことが大変だったと語った。娘の療養室は少し ずつ片づけ、自身の書斎にしたとのことである。妻の療養室につい ては人工呼吸器による加湿で、天井裏までカビが生えたとのことで 居室全体を改修し、元の応接間としての機能を一新した。

全体を通して結果を俯瞰してみると（図 2)、生活環境を新たに構 築するひとつの傾向として、逝去後の寝室の移動があるのではない かと考えた。「変化なし」以外の 9 名中 5 名 (M1, F16, F17, F18, F23) の遺族が、療養前もしくは新築後に想定していた寝室へと場を移し ていることがヒアリング調査より確認されている。寝室移動を行っ た 5 名中 3 名が療養に備えて新築していることから、住環境に対し ての意識が高かったと考えられる。このような住意識の高さが、居 間を中心とする生活環境の再構築や寝室移動などの具体的な再編に つながる行動に向かわせたと考えることができる。

\section{5. 療養室の現在と故人との関係}

5.1 療養室の現在の使われ方（図 3)

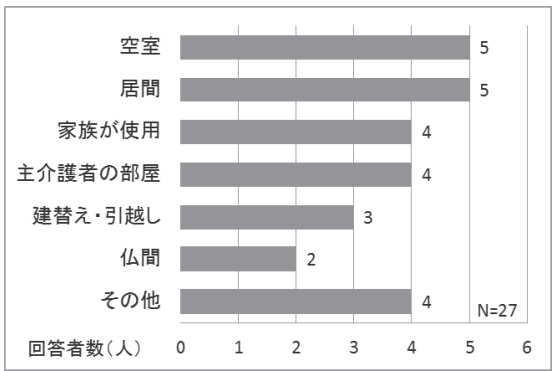

図 3 看取り後の療養室の使途

表 4 療養中・現在における療養室と仏間の位置

\begin{tabular}{|c|c|c|c|}
\hline & 療養中 & & 現在 (療養後) \\
\hline $\begin{array}{l}\text { 療養室が居 } \\
\text { 間もしくは } \\
\text { 居間との } \\
\text { 連続間 }\end{array}$ & 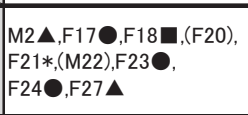 & $\begin{array}{l}\text { 仏間(遺影) } \\
\text { が居間もしく } \\
\text { は居間との } \\
\text { 連続間 }\end{array}$ & 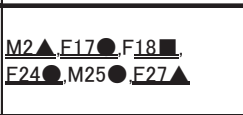 \\
\hline 上記以外 & $\mathrm{M} 1 \boldsymbol{\square},(\mathrm{F} 15), \mathrm{F} 16 \bullet, \mathrm{M} 25 \bullet$ & 上記以外 & $\underline{\underline{M} 1 \mathrm{R}, \mathrm{F} 160,(\mathrm{M} 22), \mathrm{F} 230}$ \\
\hline 不明 & 該当者なし & 不明 & (F15),(F20),F21* \\
\hline
\end{tabular}

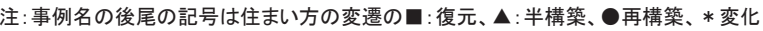
なし、()は図2未掲載者をそれぞれ示している。2重下線は療養中・現在でそれぞれの 位置が同じ類型に属しているものである。なお、記号のない者は療養中/現在の住まい 方調査が困難であり、類型の判断ができなかったため無印となっている

4.2 では住まい方の変遷を通して療養室の使われ方の変化をみた。 10 事例と少ないため、個別要素が強い部分があったが、アンケート 調查 27 件ではどのような傾向があるのかを以下で考察する。

図 3 はALS の元療養室の現在の使用状況をまとめたものである。 これをみると、バラつきはあるものの住まい方の分析にみられたよ うな空室 (誰も使用していない)、居間などが主要な使い方となって いることがわかる。なお、空室と答えた 5 名全てが現在一人暮らし となって、家族数や居室の使用が縮小していることがわかる。

\section{2 仏間/遺影と遺族の生活の場（表 4)}

療養中は療養室という罹病者の拠点があり、そこを中心として家 族の住まい方を探ることができた。その後、罹病者が故人となり、 家族が遺族となった現在の生活を考えた時、仏間や遺影の位置が現 在の故人との関係性や再編を探る糸口になるのではないかと推定し た。そこでここでは仏間／遺影の位置と住まい方との関係性に着目 し考察を行う。

図 2 には仏間・遺影の位置が示されている。これらをもとに、 4.2 でも要点となった「居間」との関係性について整理したものが表 4 である。これをみると、仏間／遺影の位置が居間もしくは居間との 連続間であった人が 10 中 6 名（M2, F17, F18, F24, M25, F27）と半数以 上を占め、そのうち 5 名（M2, F17, F18, F24, F27）は療養室の位置と 仏間／遺影の位置が共に居間もしくは居間との連続間であった。最 も該当者の多い再構築を行った遺族においても 5 名中 3 名 (F17, F24, M25)が居間もしくは居間との連続間に仏間／遺影をしつ らえていた。療養室を新たにする一方で、故人との関わりを維持し ようとする対立的な住要求が表出されている状態にある。これを高 齢者の既往研究と比較してみると、在宅サービスを受ける高齢者 8 例の場合、仏壇の置き場所は専用の部屋（2 事例）、「客」の部屋（2 事例)、「寝・客」の部屋（3 事例）、寝」の部屋（1 事例）の 4 パタ ーンがあるとされており、本研究で多くみられた居間もしくは居間 との連続間（居・食・客に該当）と異なる傾向がみられた ${ }^{3}$ )。その 要因としては 5 年以上の長期療養の末に配偶者を亡くし（F24，M25 注 11) )、逝去後 3 年以内に調査を行った対象者（F17, F24, M25）であ ることが影響したのではないかと考えられた。

事例別に詳しくみると、仏間との関係が近いタイプの特徴として 
は、M2, F18, F27 を除く 4 名が新しく仏間をしつらえたことである。 特に F24 は元々の仏間があったにもかかわらず、夫の祭壇を自分の 寝室（居間との続き間）に用意し、いつも襖を開けて夫の顔が見え るようにしているという。そして、おはよう、おやすみなどのあい さつに加えて、夜は「今日こんなことがあったのよ」と毎日話しか けていると語る。そしてそれは「とても自然な行為」であるという。 同じくF17, F18 も居間もしくは居間から見える位置に遺影を飾り、 何かあれば聞いてもらっているという。M2 も亡くなってから 1 年ぐ らいは仏壇にもご飯を供え、好きな花を手向け、いつも遺影に話し かける生活を行っていたが、気力が衰えてからは忘れる日が多くな ってきている。それでも、遺影を眺めない日はない。他方、配偶者 ではなく、娘に当たる F27 は意識的に母を思い起こすことはない。 「私、母が亡くなる半年ぐらい前かな、急に『お母さん、産んでく れてありがとう』って言葉が自然に出たの。それで母も私がいなく てもこの子たちやっていけるよって思ってくれたのかなって思うん だ」と語り、F27 はその言葉を母に伝えられたことで、その後、実 家からの独立に踏夕切ったように感じられた。

他方、仏間が離れている 3 事例は三者三様である。M1 は旧農村住 宅であり、元々の仏間に自然に遺影を飾った。客間の隣りというこ とや、お茶飲みが盛んな地域性もあり、客間が寂しくなることもな い。F16 は嫁という立場であることもあり、義母の仏間に日常的に 手を合わせる習慣はない。義父の近くなら寂しくないだろうという 部分と、居間に仏間をしつらえることへの抵抗感もある。F23 は罹 病者の逝去後、新しい生活に人一倍思いを馳せたこともあり、遺影 や仏間を居間から見える所には置いていない。できるだけ新しい生 活に目を向けたいという強い意志がここにも窥える。

療養後期には人工呼吸器を装着したり、呼吸が続かなかったりし て意思の疎通が困難となるALS であるが、その一方通行的な会話と いう意味では確かに大きな変化はないのかもしれない。「(故人が) 何か答えてくれるわけじやないんだけど、つい話したくなるのよ称 （F24）」。療養中に意思伝達装置や透明文字盤、読唇などの少しの合 図で意思確認を行ってきた長年の慣習が影響していることが考えら れる。現在も、生前と同じように今日の出来事を話し、生前と同じ ように故人を尊敬しているという。故人になっても関係が変わらな いという発言が仏壇／遺影の位置や生活にも表れていた。

\section{6. 失われた住まいと経年変化による環境移行}

\section{1 “残す”住まい（図 4)}

M22 は対象とした 27 事例のうち、震災で住まいを失った唯一の事 例である。唐突に住まいが奪われたことがその後の住まい方にどの ような影響を及ぼすのかを事例的に捉えるため、ここでは M22 を取 り上げて分析を行うこととする。

M22 は妻の発症後、療養に適した病院近くの中古住宅を購入し、 そこに移り住んだ。元の住まいはそのままの状態にした。しかし、 東日本大震災により家はほとんど津波に流され、妻を抱えながら水 面から顔を出し、命がつながったという。そこから、元の住まいで 1 年 2 ケ月の療養生活を送ることになる。居間にベッドを並べて設 置し、一心同体となって残された時間を大事に過ごした。M22 の場 合、妻が人工呼吸器を装着しないという意志が強固にあり、呼吸が 微弱になっていく様を逐次観察できたため、死期が予測でき、妻も

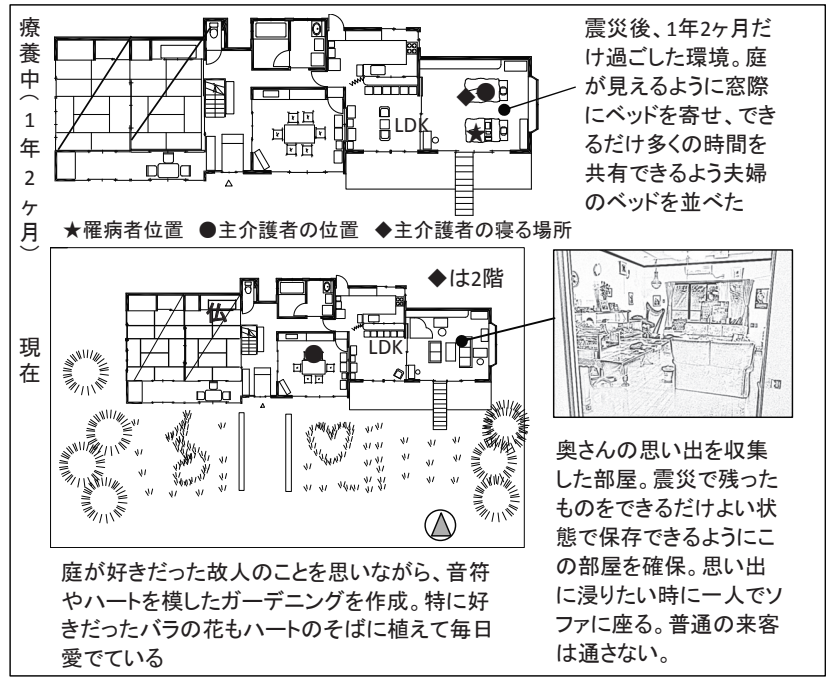

図 4 M22 と故人の住まい

また自分の最期を感じ、たくさんの遺言を残して亡くなった。その ことが、今の M 22 を大きく支えているのだといい、今も妻の宿題を こなしているという。

看取った後の住まいに療養の影はない。まるで小さな博物館のよ うに故人の写真、手記、手紙などがきれいにちりばめられ、故人が 好きだったピア)（津波で土台のみ）、ハープなどが飾られている。 多くのものを津波で失ったこともあり、少しでもゆかりのあるもの は保存し部屋に留めることを心がけている。普段は茶の間で生活し ているが、故人を偲びたい時だけ元療養室に来て、思い出の品に囲 まれながら故人と静かに会話をするという。大切な人はもとより、 震災によって多くのものを失った遺族にとって、これ以上何も失い たくないという思いが住まい方にも投影されており、それが他事例 と一線を画寸結果となっていた。

\section{2 生活環境における経年変化と環境移行（図 5)}

M2 は遺族となって一人暮らしとなった後、自ら希望した転居以外 で環境移行を余儀なくされた事例である。ここで詳しくみることと する。

M2 の療養中から没後 2 年後までの住まいは図 2 にも示した通りで あるが、そこからさらに継続調查を 3 回 (2013.12、2014.5、2014.8) 行い、関係性の変化とともにまとめたものが図 5 である。これをみ ると、住まいの変化は僅かでも人の関わり量に大きな変化があるこ とがわかる。療養開始から療養後期においては、医療看護系の訪問 スタッフが充足するとともに、患者会のつながりなども罹病者を中 心に拡張していく。しかし、罹病者が亡くなってしまうと、在宅支 援ネットワークの範囲から外孔、毎日訪問してくれる人が誰もいな くなる。息子や娘たちも年 2 回程度の訪問となるなど、寂しさが助 長される生活が展開されていく。この状況を心配に思った筆者は、 調査時に「ご近所関係はどうですか?」という質問を行った。M2は 「お母さんがいたときには時々募物どが持ってきてくれだりしたけ ど、今はさっぱり来祀え。おどごが一人になると近所の人もやっ ぱり来にくいんだよ。持ってきてくれたの、奥さんだから、ほら。 それはしょう䄈えごなんだ」と言う。そこで「そんな男性がとか、 女性がとか関係あるのですか」と再び質問すると、「いやあ、狭い世 界だがら、そういうのってさ、勝手にいろいろと噂されるんだよ。 今だって（筆者の）車止まってるけど、あれ誰が来てるな一、誰だ 
ベなーって思ってるんじゃないの」と答えた。近隣関係が閉鎖的な 地方部において、男性の一人暮らしに女性が一人でおすそ分けを持 っていくということは、非日常的な光景に映りやすいことが確認さ れ、それがより M2 のつながりの希薄化を強めていることが伺えた。

では、このような孤独な状況に気が付く人は他にいなかったのだ ろうか。筆者も M2 の様子を気がかりにしていたが、長期において関 わっていた訪問看護師もまた、気がかりになっていたという。そこ で県の保健師に相談するなど連携を図っていたというが、保健師に 実際に状況を尋衫ると「他にもっと大変な人はいる（M2 の状況には まだ猶予がある)」と返答された。訪問時には少なくとも元気そうで、 あまり保健師に関わりたがらないとのことであった。M2 は皆に「男 性なのに介護をきちんとして素晴らしい人」と言われていたその過 去を共有できる人でなければ心を開けなかったのではないかと推察 する。そうして、少しずつ $\mathrm{M} 2$ への関心が薄まっていく中で、ついに M2 は重度のアルコール依存症となり、栄養失調も相俟って救急搬送 されることとなる。住み慣れた住まいでの生活から切り離されるこ とを余儀なくされた。その後、心身状態の回復・リハビリを経て退 院となったが、一人での生活は厳しいと M2 の娘が判断し、M2 に許 可を取らぬまま有料老人ホームに入所することが決定された。不本 意ではありながら、自分でリハビリをして問題なく自力歩行ができ るようになれば家に帰れると信じ、今は自主的なリハビリに励んで いる状態にある。

罹病者が亡くなって 2 年以内に、何らかの支援や生活環境を立て 直すきっかけがなかったことが悔やまれる事例である。

\section{7. まとめ}

長期在宅療養を行った ALS 遺族の療養中から現在までの住まい方 の変遷を中心に考察した。以下に結果をまとめる。

1 ) 住宅形態は地方連続間型が 4 事例、都市 LDK 型が 6 事例であり 療養中は居間もしくは居間との連続間で療養していた事例が 7 割を 占めた。このような療養室の位置の特性は在宅サービスを利用する 高齢者やがんにおける先行研究でも見られており、同サービスを利
用していた ALS においても例外ではないことが確認できた。

2 ）罹病者の逝去後の住まいは模様替えをはじめとし、何らかの手 が加えられることが確認できた。その類型としては復元・半構築・ 再構築・変化なしの 4 パターンであり、再構築を行う人が最も多く みられた。再構築を行う要因としては、居間に療養室があったこと、 新しい環境で再出発をしたかったことなどが挙げられた。再構築対 象者の 5 名中 3 名が療養のために新築していることから、兼补てよ り住まいに対する意識が高かったことが考えられ、それが一つの要 因となって療養後の再編や寝室移動などの具体的な行動へ向かわせ たと考えられる。反対に、天災や経年変化により住み慣れた地域で 住み続けられなくなった場合、故人に関わる物を意図的に集めたり するなどの環境整備に関する意欲が増長したり、訪問者の減少や周 囲の遺族への関心の薄れなどにより生活意欲が減少したりする状況 が事例より確認された。

3 ) 仏間／遺影の位置が居間もしくは居間との連続間であった人が 10 名中 6 名と半数以上を占め、そのうち 5 名は療養室も同位置にあ った。亡くなった後も故人を感じられる遺影や仏間の位置が居間に 近いことが確認された。該当者の多かった再構築を行った 5 名のう ち 3 名においても同様の傾向がみられており、療養室を新たにする 一方で、居間に仏間／遺影を飾るなど故人との関わりを維持し続け る対照的な住要求が混在している状態にある。その要因として再構 築者にみられたことは、 5 年以上の長期介護の末に罹病者を看取っ たこと（2 名）、調查が逝去後 3 年以内に実施されたこと（3 名）で あり、それらが影響していることが考えられた。住まいに対する潜 在意識や療養期間の長さ・住まい方、故人との関係性が複合され療 養後の住まいを形成することが確認された。

本調查は限られた地域の限られた遺族における調查を基としてい るため、ALS 罹病者遺族の生活環境の一般論を語るには限界がある。 そのためここでは事例調查を通じて、遺族が療養を開始してから療 養を終えた後の生活環境の再編過程を断片的であるにせよ、明らか にすることを目的としている。遺族というデリケートな対象に調査

\begin{tabular}{|c|c|c|c|c|c|}
\hline & & $>$ & & & \\
\hline 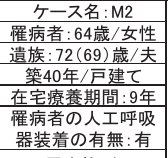 & 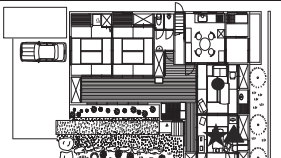 & $\frac{|\theta|}{\mid \underline{|l|}}$ & 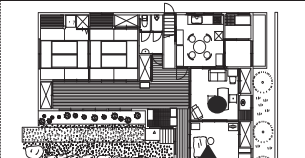 & 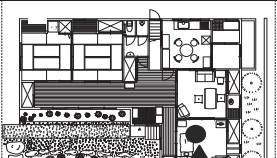 & -厶 \\
\hline $\begin{array}{l}\text { 同居家族:なし } \\
\text { 家族:息子2名(県內 }\end{array}$ & & $+0.40,000$ & y. & & 過ご \\
\hline $\begin{array}{l}\text { 名、県外1名)、娘 } 1 \\
\text { 罧内) }\end{array}$ & 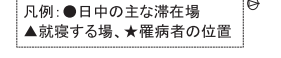 & 療養室を & & ぐらいから & $\begin{array}{l}\text { す日 } \\
\text { は伐 }\end{array}$ \\
\hline 住宅改修の有無: 有 & & $\tau \notin$ & 待古、 & & \\
\hline 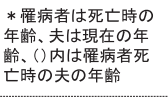 & $\begin{array}{l}\text { 応接間だった和室を療養室として } \\
\text { しつらえた。 } \\
\text { 居室は8畺。夜は夫が添い寝して } \\
\text { 付き添う。 }\end{array}$ & $\begin{array}{l}\text { 㐫者に、部屋をでき } \\
\text { があるため、入院 } \\
\text { 間に改修。しかし、、 } \\
\text { 。。 }\end{array}$ & 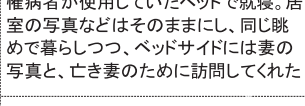 & $\begin{array}{l}\text { ほぼ飲酒だけけの生活となる。近く } \\
\text { にいる娘や息子の足も少しずっ } \\
\text { 遠のいていく全ての行動が寝室 } \\
\text { 1室になる。 }\end{array}$ & $\begin{array}{l}\text { 調ならて } \\
\text { きなくな } \\
\text { も,在宅 } \\
\text { で娘が }\end{array}$ \\
\hline $\begin{array}{l}\text { 凡例 } \\
- \text { 医療·看境 } \\
\text { スタッフ } \\
\text { - 同病者、 } \\
- \text { 血緑者 } \\
\text { 罹病者 } \\
\text { 主介護者 }\end{array}$ & $\rightarrow$ & & 2回 & 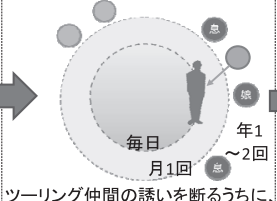 & \\
\hline $\begin{array}{l}\text { 女性男性 } \\
\text { 療養当初の同居家 } \\
\text { 会社を辞め、日中0 } \\
\text { 伝う介謢体制。家方 } \\
\text { 関係を少しずつ構 } \\
\text { る。 }\end{array}$ & 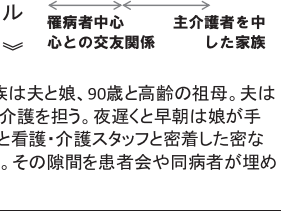 & 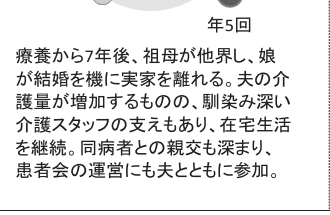 & $\begin{array}{l}\text { 家族が心配して } \\
\text { 車につれ、療 } \\
\text { 絡になる。 } \\
\text { 動や介護スタッ } \\
\text { 友人からの誘 } \\
\text { 丈役割もなく、同 } \\
\text { な孤独が襲う } \\
\end{array}$ & $\begin{array}{l}\text { ツーリング仲間 } \\
\text { 友人関係も希荡 } \\
\text { 遺族会員として } \\
\text { ALSに触れるここ } \\
\text { う。頼りの家族 } \\
\text { に1回、馴染み } \\
\text { 診医が訪ねてき } \\
\text { 県の保健師の言 } \\
\text { ないと断って追 }\end{array}$ & $\begin{array}{l}\text { に面会に来 } \\
\text { すようになっ } \\
\text { ど来なくなっ } \\
\text { 施設スタッフ } \\
\text { 宅に早く帰れ } \\
\text { 力んでいる。 }\end{array}$ \\
\hline
\end{tabular}

図 5 M2 の住まいと人との関わり量の変化 
を行うためには長期における患者会・罹病者家族との信頼関係の構 築が不可欠であった。

\section{謝辞}

調查にご協力戴いた ALS 罹病者の遺族の方に深謝致します。なお、 本研究の一部は 2013 年度住宅総合研究財団の研究助成および科学 研究費補助金 若手 (B)「長期在宅介護を行った ALS 罹病者遺族にお ける生活環境の再編過程に関寸る研究」の助成を受けて行いました。

\section{注}

注 1 ) 介護を伴う高齢者の住まい方に関する研究は少ない。代表的なものに、 山下、山本、井上らの住まい方の研究がある。山下は住まいが寝室から病 室へと変化する様態について 39 事例を対象に考察をし、そのうちの 10 名 については食寝居が寝たきりによって同室化することを明らかにしている (1。山本らの続き間の有効性に関寸る事例的研究においては、29 事例中 6 例が終日寝室のみで行為を行っており、6 例全ての介護度が 3-5 度で高い ことが明らかになっている ${ }^{(2}$ 。井上らによる在宅サービスを受ける高齢者 に関する研究においても寝・食・居が一体・一室化している事例が 39 事例 中 22 例紹介されている ${ }^{(3}$ 。

注 2 ) ALS の大きな特徴として、(1)家族の介護時間・期間が長さ、(2)知能な どに関わる高次機能が維持されるため、罹病者の人間的尊䢅と生活の質が 問われることがある。同様に長期在宅療養が必要な疾患として、高龄者に かかわるアルツハイマーやパーキンソン病などの慢性的なケアや交通事故、 脳血管障害などによる寝たきり者、神経系疾患が挙げられる。介護期間を 一律に比較できないが、厚労省によれば介護時間においては、高龄者は「必 要な時に手を貸す程度」が $40.2 \%$ と最も多く、次いで終日介護が $22.8 \%$ とな っており、介護度によるが概数 3 割程度介護時間が長い対象者がみられる 状態であると推察される（平成 26 年度高齢者白書）。ALS と脳血管障害・ 交通事故による寝たきり者との比較では、ALS では $8.8 \pm 2.5$ 時間/ 1 日、 寝たきりでは、 $3.3 \pm 1.2$ 時間/ 1 日と ALS が極めて長いという結果が出て いる ${ }^{4)}$ 。またアルツハイマーやパーキンソン病を抱えた高齢者や脳血管障 害・交通事故の寝たきり者は高次機能が維持されにくいという特徵がある。 本研究では ALS の上記 2 つ特徵が遺族の療養後の生活環境に影響を与え ると仮定し、長期療養を伴う者の中でALS 罹病者遺族を対象とした。

注 3 ) 調査地は 5 府県である。この 5 府県の特徴を概括的に捉えるために、 下記の資料を基に整理した。図は介護サービス施設・事業所調查(平成 21 年)および人口動態調査 (平成 21 年) をもとに自宅死亡の割合と訪問看護利 用実人数（高齢者千人当たり）の関係性を示している。これをみると、調 查地である大阪・宮城は全国的に見て訪問看護利用率・自宅死亡割合が高 位であるのに対し、山形・愛知・岩手はほぼ全国平均の都道府県であるこ とがわかる。また、住宅の特徴については鈴木によれば東北南部は「住宅 は和風で平面型は間口方向に和室が並ぶ『ヨコ型続き間』が多く、和室が 多い」こと、東海地方は「住宅の規模は大都市としては大きく間取りも続 き間座敷が多い」こと、大阪圈においては「敷地が狭いものが多く、1 階 を駐車場にした 3 階建ての多さに特徴がある」ことを挙げており、大阪を 除いて概数続き間（連続間）を有する住宅が一般的と考えられる ${ }^{(13}$ 。

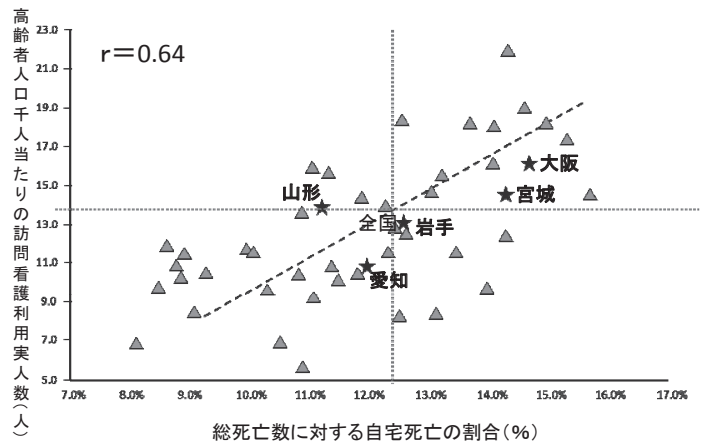

注 4 ) 調査はデリケートな遺族を対象と寸るため、筆者らと長年の信頼関係 がある山形県、宮城県、愛知県、大阪（近畿ブロック）を対象とした。そ の他、近畿ブロック以外で独立している患者会である滋賀県支部、ALS み えなどにも遺族調査を依頼し、半年かけて何度か連絡を取り合ったが、具 体的な遺族の紹介に至らなかった。信頼関係が構築できていない地域にお
いては調查依頼それ自体の困難さが発生した。

注 5 ) 基本的な調查は 2012.8 2013.8 までに行ったが、追加調査が可能であ った M2 の事例のみ 2013.12、2014.5、2014.8 においても調查を実施してい る。追加調查の時期は、 12 月：入院直後、5 月 : 老人ホームへの転居後 2 ケ月、8月：転居後半年で心境の変化を捉えた。

注 6 ) 山本和恵、亀屋惠三子 : 看取りをめぐる家族像とすまいの変容に関す る研究、pp14、第一住宅建設協会 調査研究報告書、2003.5 より結果を引 用した。山本らは「すまい」の中で医師や訪問看護師、家族が如何に支え ているのかを「看取り環境」より明らかにしている。調査は往診を行って いる診療所を利用した遺族 186 名へのアンケート調查および 5 名への訪問 調査に基づいて行っている。アンケート調査では療養が長期になるに従い ストレスを感じる人が多いこと、続き間での療養を行う人が 7 割に及ぶこ とが明らかになっており、事例調查によって居間もしくは居間との続き間 で療養を行う人が 5 名全てに該当したことなどが明らかになっている。

注 7 ) ここでいら地方連続間型とは、鈴木 ${ }^{13)}$ の「地方続き間型住宅」を参考 にし、(1) 1 階に南面に面して二つの連続した居室あること、(2) 1 階には DK と居間があり、老人の部屋や応接間が設けられていること、(3)廊下、ホー ルがこれらの諸室を繋ぐ形態を持つものとする。

注 8 ) 本研究における都市 LDK 型とは鈴木 ${ }^{13)}$ と同様に、(1)廊下によって他室 を通らずに各室に達することができ、(2)洋間の居間（L) と食堂（D）があ るものを概括的に捉えた。

注 9 ) 最初に整理したものとして機器やベッドなどのレンタル品を整理した 人は複数回答で 18 人中 16 人おり、回答数の 7 割を占める。

注 10）片付けを始めた時期は、回答のあった 22 名のうち、「すぐに」と答 えた人が約 6 割を占めた。平均すると片付けに取りかかるまでの時間は 3 ケ 月であり、F17, F 24 は平均よりも早めに片づけたことがわかる。

注 11）M25 は2 名の ALS 罹病者を看ており、娘、妻の順で亡くしている。 娘の介護は 5 年以内でかつ逝去後から 3 年以上経過しているが、妻の方は 5 年以上の長期、逝去後 3 年以内に属するため、ここでは最後に亡くなっ た罹病者を基準に分析を行った。

\section{参考文献}

1) 山下哲郎 : 在宅患者の生活様態に看る療養環境の素形 その 1 、日本建 築学会計画系論文集 第 545 号、pp. 167-172、2001.7

2 ）山本和恵、西田幸子 他：要介護高齢者の住まい方にみる続き間の有効 性に関する事例的考察一個の社会課と住まいの開放化に関する研究一、日 本建築学会計画系論文集、第 586 号、pp. 17-23、2004.12

3 ) 井上由起子、小滝一正 他 : 在宅サービスを活用する高齢者の寸まいに 関する考察、日本建築学会計画系論文集，556、pp. 137-143、2002.6

4) 阿南みと子：人工呼吸器を装着した ALS 在宅患者の介護者の生活時間と 疲労、日本難病看護学会誌、5 (2)、pp. 117-122、2001

5 ）亀屋惠三子、菅野實 他：長期療養の場としての ALS 罹病者と家族の住 まいに関する事例的研究、日本建築学会計画系論文集, 593、pp. 41-47、 2005. 7

6 ) 長島梢、野村歓 他: 筋萎縮性側索硬化症者の住環境整備に関する研究、 日本建築学会計画系論文集 73，623、pp.9-15、2008.1

7 ）坂口幸弘、柏木哲夫 他 : 家族機能認知に基づく死別後の適応・不適合 家族の検討、心身医学 39 (7) 、pp. 525-532、1999.10

8 ) 島内 節、小野 恵子 : 遺族による在宅ターミナルケアのサービス評価、 日本在宅ケア学会誌 12 (2)、pp. 36-43、2009.2

9 ) 松井 由美、山口 信代 他: 訪問看護師の在宅での看取りに対する意識、 日本看護学会論文集. 地域看護 44、pp. 15-18、2014

10）須永恭子、田村須賀子：訪問看護師が捉える看取りの課題とその背景に 関する検討、ホスピスと在宅ケア $22(1) 、 p p .21-30 、 2014.5$

11）山本和恵、亀屋惠三子 : 看取りをめぐる家族像とすまいの変容に関する 研究、第一住宅建設協会研究報告書、2003.5

12）大槻恵子、橋本洋一郎：がん終末期の住環境整備と在宅での看取りに関 寸る事例検討、文京学院大学人間学部研究紀要、pp. 303-321、2010.12

13）鈴木成文：住まいを読む、建築資料研究社、1999.

14）亀屋惠三子、山本和恵 他：療養中から死別後の住まいの再編に関する 事例的研究一在宅介護を行った遺族を対象として一、住総研 研究論文集 No. $40 、$ pp. 47-58、2013 年版

15）亀屋惠三子、竹平 遥 他：ALS 罹病者の遺族における生活環境の再構築 に関寸る事例的研究 その 2 . 事例にみる住まい方の変化、日本建築学会大 会学術講演梗概集, E-2 分冊, 建築計画、pp. 1267-1268、2013.8 


\section{STUDY OF THE RESTORATION PROCESS OF THE LIVING ENVIRONMENTS OF BEREAVED FAMILIES THAT HAD UNDERTAKEN LONG-TERM AT-HOME CARE FOR ALS PATIENTS}

\section{Emiko KAMEYA* and Kei ADACHI**}

* Assoc. Prof., Dept. of Civil Engineering, Kobe City College of Technology, Dr.Eng.
** Prof., Dept of System Engineering, Wakayama Univ, Dr.Eng.

By focusing on the changes that can be made to houses to establish a point from which bereaved families can return to their communities, with the aim of clarifying the course of house restoration from a nursing to a living environment, we conducted a questionnaire survey of affected families, and a case-based survey to understand the space available in their homes after undertaking the long-term at-home care of an ALS patient.

1) We describe our analysis on the locations of care rooms and house layouts. We found that, after the death of an ALS patient, the houses in which they had been cared for could be roughly classified into four types, namely, restoration, partial restoration, reconstruction, and no change. Most bereaved families undertake reconstruction. This trend was most commonly seen in urban LDK-type houses. Factors affecting the reconstruction included the fact that a house's living room had been used as a care room and that a bereaved family wanted to live a new life in a new environment. The home environment of families with an ALS patient, who showed a marked tendency to use the living room as the care room can greatly benefit to the restoration of their living environments after the death of the patient.

2) We discuss the current usage of care rooms and the locations of rooms used for Buddhist rituals. As a result of our analysis of home environments, we found that care rooms have become spare rooms (not used by anyone), living rooms, etc., despite variations in those environments. All of the five respondents who stated that their care room was now vacant, currently live alone. This indicates that the number of members in their family has fallen, or that they have "downsized." Bereaved family members, who had lost their spouses after long-term at-home care, showed a marked tendency to use a living room or habitable room adjacent to the living room as the room for Buddhist rituals or to display photos of their deceased spouse. 